\title{
MAPEAMENTO DE MODELOS DE DESIGN DE INTERAÇÃO PARA CIDADES INTELIGENTES
}

Iluriel Andrade Teixeira

Universidade do Estado de Minas Gerais

iluriel@outlook.com

Resumo: Este estudo apresenta os resultados de um projeto de iniciação científica orientado pela Profa . Drạ. Fernanda da Costa Portugal Duarte na Escola de Design, UEMG. A pesquisa analisa e propõe soluções de design de interação para "cidades inteligentes". As "cidades inteligentes" são sistemas que procuram incrementar a qualidade de vida e o conforto do ser humano por sistemas interativos com alto nível de usabilidade e flexibilidade que atendam às necessidades dos cidadãos. Imagine uma casa totalmente automatizada, que ajusta temperatura e luminosidade de acordo com as preferências de conforto térmico e de luminosidade do usuário. Veículos que, além de dirigir, procuram vagas e estacionam autonomamente. Ou ainda, fluxo variável de transporte público cuja oferta e rota sejam alteradas em tempo real para atender a demanda da população em situações atípicas como chuvas e eventos. Moradores que recebem notificações de alerta em seus smartphones em situações de emergência, como tempestades e inundações, para que assim pudessem se preparar ou buscar ajuda. Esta realidade já está em desenvolvimento em diversas "cidades inteligentes" ao redor do mundo, dentre elas podemos citar Songdo (Coréia do Sul), Mitaka (Japão), Tianjin (China), Singapura, Hong Kong, Estocolmo (Suécia), Barcelona (Espanha), Waterloo (Canadá) e Porto Alegre (Brasil). Por ter uma alta conectividade de redes de comunicação sem fio, estas cidades são ambientes propícios para teste e implementação de modelos de automação e arquitetura de informação. $O$ desenvolvimento destas cidades só é possível devido à evolução de sensores discretos e processadores que conseguem minerar quantidades colossais de dados que são coletados a todo instante, interpretando em tempo real qual é a necessidade de cada região e o que pode ser feito para atendê-la. Diante desta realidade, este projeto cataloga e analisa modelos de sistemas interativos de "cidades inteligentes". Esta pesquisa analisa as formas de coleta e processamento de dados que alimentam os sistemas, e apresenta diagnóstico dos modelos das cidades já existentes na Ásia e Europa. Em seguida, estabelece uma análise comparativa entre estes modelos e os processos de sistemas interativos instalados na cidade de Belo Horizonte. Esta comparação tem como objetivo contrastar e identificar oportunidades de desenvolvimento de sistemas interativos para Belo Horizonte. Como os designers possuem profunda relação com aplicação de tecnologias emergentes, ambiente típico nas "cidades 
inteligentes", percebe-se a potencial relevância do design na construção de pontes entre o homem e a máquina, tornando possível observar o que seriam de fato estas transformações de uma cidade comum para uma cidade inteligente. Com a visão sistêmica que o design possui é possível ir além da infraestrutura tecnológica e mineração de dados, ressaltando as formas de inserção social de tecnologias e processos criativos que deixarão um lastro mais flexível para a atuação do design de interfaces.

Palavras-chave: Design de interação, Cidades inteligentes, sistemas interativos, megadados 